\title{
The International Red Cross and Red Crescent Movement Response \\ to the West African Ebola Outbreak 2014
}

\author{
Christy Shucksmith-Wesley
}

\begin{abstract}
The International Health Regulations 2005 (IHR) are the most up to date international legal rules on the control of infectious diseases and provide a unified code for infectious disease control. The IHR name the International Federation of the Red Cross (IFRC) as one of the international organisations with whom the WHO must cooperate and co-ordinate in implementing the IHR. It was organisations like the IFRC and MSF, that worked to stop the spread of Ebola following the outbreak in 2014. The focus of this chapter is the work of the IFRC during the Ebola outbreak. The IFRC carries out relief operations to assist victims of disasters, and combines this with development work to strengthen the capacities of its member National Societies. The IFRC's work focuses on four core areas: promoting humanitarian values, disaster response, disaster preparedness, and health and community care. Combining a study of the IFRC as an organisation with a legal mandate of its own, elucidated in the Statutes of the International Red Cross and Red Crescent Movement, and the more general international legal framework, this chapter uses international law as a framework to reflect on the limits and effectiveness of legal measures in responding to Ebola. To this end, international law provides a logical and global method to respond to infectious diseases. This chapter finds that the mandate and practice of the IFRC in the response to Ebola provides material to critically analyse each of these parts in light of infectious disease proliferation in 2014-2016. Since outbreak was announced in early 2014 more than 10,000 Red Cross volunteers were trained in Ebola response. IFRC supported emergency operations in Guinea, Liberia, and Sierra Leone have targeted 23 million people.
\end{abstract}

Keywords Red Cross $\cdot$ Ebola $\cdot$ Humanitarian assistance $\cdot$ WHO $\cdot$ Collaboration Ebola

\footnotetext{
C. Shucksmith-Wesley ( $\varangle)$

University of Nottingham, Nottingham, United Kingdom

e-mail: Christy.shucksmith-wesley@nottingham.ac.uk
} 


\section{Introduction}

The purpose of this chapter is to show the legal and practical relationships between the International Federation of the Red Cross (IFRC) and the World Health Organisation (WHO) during the West Africa Ebola outbreak in 2014. Taking Sierra Leone, Liberia and Guinea as examples, this chapter considers the mandate and functions of the International Red Cross and Red Crescent Movement (IRCRCM) and whether its mandate complements, or otherwise competes with, the infectious diseases and international law framework and regulations. The Red Cross mandate includes the provision of health care to civilians and combatants during conflict and disaster situations. ${ }^{1}$ This will be described in the first part of the chapter. The Red Cross is not, however, alone in this role. The WHO, ${ }^{2} \mathrm{MSF},{ }^{3}$ military actors, ${ }^{4} \mathrm{NGOs}$ and local actors all interlink and, hopefully, coordinate in the preparation for, response to, and rebuilding after the outbreak of an infectious disease. ${ }^{5}$ Outbreak response will require medical assistance, possibly the participation of Emergency Medical Teams, and a rapid response in the areas of water, sanitation and hygiene, shelter and food. ${ }^{6}$

Kamradt-Scott et al. argue that the Ebola outbreak in Guinea, Liberia and Sierra Leone proved to be an exceptional outbreak that blurred the lines between health and humanitarian crises. In so doing, it highlighted numerous problems with regard to the coordination of humanitarian disasters that have public health implications of international consequence. ${ }^{7}$ In that context, this chapter shows the extensive mandate of the IFRC, and provides a critique of an institution that is widely underappreciated in the literature concerning global health, emergency medicine and humanitarian responses. The Red Cross is a unique humanitarian organisation with an arguablyunparalleled operational mandate to provide essential humanitarian protection and

\footnotetext{
${ }^{1}$ Statutes of the Red Cross and Red Crescent Movement (adopted by the 25th International Conference of the Red Cross at Geneva in 1986, amended in 1995 and 2006), preamble and principle of humanity, art 3(2) National Red Cross and Red Crescent Societies, and art 6(4)(f) IFRC; Resolution 7 of the 31st International Conference of the Red Cross Red Crescent on 'Strengthening normative frameworks and addressing regulatory barriers concerning disaster mitigation, response and recovery' (12 January 2011); Resolution 6 of the 32nd International Conference of the Red Cross Red Crescent on 'Strengthening legal frameworks for disaster response, risk reduction and first aid' (10 December 2015).

${ }^{2}$ Constitution of the World Health Organisation Constitution, reprinted in Basic Documents, Fortyfifth edition, Supplement, October 2006 art 2(a), (b).

${ }^{3}$ Medecins Sans Frontiers mandate, https://www.msf.org.uk/?gclid= EAIaIQobChMIxPyCiLOT2AIVQ7HtCh3RqQtREAAYASAAEgIBxvD_BwE.

${ }^{4}$ Kaplan and Easton-Calabria (2015): MSF, which is a private, international association, has the mandate to 'bring humanitarian medical assistance to victims of conflict, natural disasters, epidemics or healthcare exclusion'.

${ }^{5}$ Research Paper Ross et al. (2017).

${ }^{6} \mathrm{WHO}$ and IFRC (2017a).

${ }^{7}$ Kamradt-Scott et al. (2015).
} 
assistance to populations in need. The nature of its operations is described in this chapter. This chapter provides an analysis of the relationship between the WHO and the IRCR. It builds on previous work that showed that the ICRC is an international legal person that has an international legal mandate to protect those in need during armed conflict. ${ }^{8}$ That work examined the governance structure of the Movement and showed that the Red Cross and Red Crescent Movement is an institution with power and authority across multiple humanitarian situations, including disasters, armed conflicts, and other situations of violence. ${ }^{9}$

The WHO and IFRC each take their rights and duties from international agreements signed by States, but their working methods make them very different actors. The National Societies of the Red Cross, such as the Liberian Red Cross Society, ${ }^{10}$ Red Cross Society of Guinea ${ }^{11}$ and the Sierra Leone Red Cross Society, ${ }^{12}$ are auxiliaries to governments and are supported by the IFRC. The IFRC works through the existing networks on the ground in the provision of humanitarian aid and protection. The primary role of the WHO is the attainment by all people of the highest possible level of health. ${ }^{13}$ In order to achieve this, the functions of the WHO, detailed in Article 2 of the Constitution of the WHO, establish the WHO as the directing and co-ordinating authority on international health work'. ${ }^{14}$ Article 2 outlines the WHO relationship with States, the United Nations, specialised agencies, governmental health administrations, professional groups and such other organisations as may be deemed appropriate. As with any international organisation, and the Red Cross Movement, the WHO assists Governments at their request and/ or with their consent. Its activities encompass technical support, the provision of aid, and health care (covering emergency assistance and also the overall improvement of international health). If we were to directly compare the WHO with the IFRC, we could say that the key similarity is the human-focused agenda which can only be realised through a State-centric system and is therefore dependent on consent. The key difference is the working method of each entity, as the IFRC is able to mobilise National Societies and support local actors and work towards health goals identified by the citizens, local groups and regional bodies. The WHO is much more hands-off, as it acts as a co-ordinating authority. We can see, therefore, that the WHO and IFRC have the ability to positively affect the ability of States to respond to infectious diseases, but with very different strategies and approaches; how these approaches compliment

\footnotetext{
${ }^{8}$ See Shucksmith (2017).

${ }^{9}$ Ibid.

${ }^{10}$ Liberian Red Cross Society, http://www.ifrc.org/en/what-we-do/where-we-work/africa/liberianred-cross-society/.

${ }^{11}$ Red Cross of Guinea, http://www.ifrc.org/en/what-we-do/where-we-work/africa/red-crosssociety-of-guinea/.

${ }^{12}$ Sierra Leone Red Cross Society, http://www.ifrc.org/en/what-we-do/where-we-work/africa/ sierra-leone-red-cross-society/.

${ }^{13}$ For an excellent text on the WHO, see Lee (2009).

${ }^{14}$ Art 2 (a) Constitution of the WHO.
} 
or clash (as the case may be) during a health emergency is the focus of this chapter. With this in mind, this chapter shows the relationship between these two institutions and critically appraises the contribution of the IFRC to the Ebola response in 2014. It examines the coordination role of the WHO and the extent to which the IFRC is coordinated by the WHO and, on the other hand, the areas in which it exercises its autonomy and its own legal mandate.

This chapter critically considers the role of the IFRC in the multi-agency response to Ebola and whether it sits within the response envisaged within the IHR or whether it acts under its own international mandate. The National Societies and the IFRC have local knowledge, expertise and resources to provide a first response to an outbreak. Through its networks, it can coordinate with MSF and other NGOs. However, the WHO is responsible for the overall coordination of all responders. ${ }^{15}$ Within this leadership role, I argue, the WHO must respect the international legal mandate of the IFRC and the roles that it has assumed. The WHO has the benefit of acting on the international stage and being able to speak to all actors, but the IFRC is better placed to manage the specific situation on the ground. Overall the chapter will examine what coordination is done by the WHO via the IHR; what is done by the UNGA; and what is done by the RCRCM. It will show the gaps in coordination and critically appraise the independent contribution that the IFRC makes to the response to the outbreak of infectious disease.

\section{Red Cross and Red Crescent Mandate}

The Red Cross Movement is comprised of the ICRC, IFRC, and National Societies. The ICRC and the IFRC have headquarters in Geneva, whereas the National Societies are based in States. The ICRC is the 'guardian of international humanitarian law', with a mandate, taken from the Four Geneva Conventions, to provide humanitarian protection and assistance during international and non-international armed conflicts. $^{16}$

The ICRC works at the intersection of human needs, state sovereignty and international organisations. It is grounded by its principles and has access to state officials and the local population. It has influence within states and on the international stage, particularly through the International Conference and its observer status at the UN General Assembly. ${ }^{17}$ The ICRC can act with legal effect and develop its competences on the international stage. Taken together, the current legal framework and

\footnotetext{
${ }^{15}$ Art 2(a) Constitution of the WHO.

${ }^{16}$ Council of Delegates (ICRC), 'Agreement on the Organisation of the International Activities of the Components of the International Red Cross and Red Crescent Movement-The Seville Agreement' (Council of Delegates, ICRC, 25-27 November 1997). www.icrc.org/eng/resources/ documents/misc/57jp4y.htm, preamble (Seville Agreement).

${ }^{17}$ Koenig (1991).
} 
humanitarian protection and assistance strategies allow the ICRC to provide food, healthcare, shelter and water to those in need.

The Red Cross Movement began in 1864 but at the end of the Second World War, with the adoption of the Geneva Conventions I-IV, it truly took on a life of its own. States have consented to the presence of the Red Cross within their sovereign territory through a series of international agreements, including the Geneva Conventions I-IV, ${ }^{18}$ Statutes of the Red Cross and Red Crescent Movement, Statutes of the ICRC, and individual Headquarters Agreements drawn up between the ICRC and governments. These international agreements and the governance structure of the Red Cross Movement (from Geneva, to National Societies, to the field) allow the Red Cross to respond to humanitarian situations independently of other actors. This means, for example, that although the WHO may have the power to direct and coordinate activities and policies for global health, the Red Cross can act independently: States can ask for its help directly, it can act through the National Societies of States, and it can establish specific projects through its International Conference, such as the Health Care in Danger project 2011-2015.

The Red Cross was built from a desire to provide health care for wounded soldiers. Henry Dunant envisaged an organisation with volunteer nurses and medics that would help any wounded soldiers, regardless of the side on which they fought. From these beginnings, the Red Cross has continued to develop its health care ambitions and capabilities. In part, its roles are mandated through the international agreements, to which States are parties. These roles of the National Red Cross and Red Crescent Societies include cooperation with public authorities in the prevention of disease, the promotion of health and the mitigation of human suffering. ${ }^{19}$ The IFRC is mandated to 'encourage and coordinate the participation of the National Societies in activities for safeguarding public health and the promotion of social welfare in cooperation with their appropriate national authorities'. ${ }^{20}$ In addition, the Red Cross is able to act autonomously within States owing to its international legal personality and its existing presence in each State in the guise of the National Societies. This sets it apart from other organisations.

\footnotetext{
${ }^{18}$ Convention (I) for the Amelioration of the Condition of the Wounded and Sick in Armed Forces in the Field. Geneva (adopted 12 August 1949, entered into force 21 October 1950) (Geneva Convention I); Convention (II) for the Amelioration of the Condition of Wounded, Sick and Shipwrecked Members of Armed Forces at Sea. Geneva (adopted 12 August 1949, entered into force 21 October 1950) (Geneva Convention II); Convention (III) relative to the Treatment of Prisoners of War. Geneva (adopted 12 August 1949, entered into force 21 October 1950) (Geneva Convention III); Convention (IV) relative to the Protection of Civilian Persons in Time of War. Geneva (adopted 12 August 1949, entered into force 21 October 1950) (Geneva Convention IV); Statutes of the International Red Cross and Red Crescent Movement 1986 (adopted by the 25th International Conference of the Red Cross at Geneva in 1986 and amended in 1995 by Resolution 7 of the 26th International Conference of the Red Cross and Red Crescent at Geneva and 2006 by Resolution 1 of the 29th International Conference of the Red Cross and Red Crescent at Geneva).

${ }^{19}$ Statutes of the Movement art 3(2) National Red Cross and Red Crescent Societies.

${ }^{20}$ Statutes of the Movement art 6(4)(f).
} 
There are three distinct branches of the Movement; the International Committee of the Red Cross, the International Federation of the Red Cross, and the National Societies. ${ }^{21}$ Generally speaking, the IFRC carries out relief operations to assist victims of disasters, and combines this with development work to strengthen the capacities of its member National Societies. ${ }^{22}$ The IFRC's work focuses on four core areas: promoting humanitarian values, disaster response, disaster preparedness, and health and community care. ${ }^{23}$ Its aim is to inspire, facilitate and promote all humanitarian activities carried out by its member National Societies on behalf of the most vulnerable people. As with all components of the Red Cross, it acts independently, meaning that it is not 'governmental, political, racial or sectarian in character'. ${ }^{24}$ The IFRC has access to local knowledge and expertise, through National Societies, which makes it an invaluable responder when there is an outbreak of disease.

Article 6(1) of the IRCRCM Statutes states that

[T] he International Federation of Red Cross and Red Crescent Societies comprises the National Red Cross and Red Crescent Societies. It acts under its own Constitution with all rights and obligations of a corporate body with a legal personality. ${ }^{25}$

Article 6(3) states that the 'general object of the Federation is to inspire, encourage, facilitate and promote at all times all forms of humanitarian activities by the National Societies, with a view to preventing and alleviating human suffering and thereby contributing to the maintenance and the promotion of peace in the world ${ }^{26}$ Under Article 6(4) (f) IRCRCM Statutes its functions include:

\begin{abstract}
encourag[ing] and coordinat[ing] the participation of the National Societies in activities for safeguarding public health and the promotion of social welfare in cooperation with their appropriate national authorities. Its aim is to inspire, facilitate and promote all humanitarian activities carried out by its member National Societies on behalf of the most vulnerable people. Finally, 'in each country the Federation shall act through or in agreement with the National Society and in conformity with the laws of that country'. The IFRC benefits from the local volunteers of the National Societies. It has access to local knowledge and expertise which makes it an invaluable responder when there is an outbreak of disease.
\end{abstract}

In order to participate in the IRCRCM, National Societies must first be recognised by the ICRC and then admitted by the International Federation. Article 4 of the IRCRCM Statutes provides ten conditions for recognition as a National Society. Article 4(1) states that National Societies be constituted on the territory of an independent state where the 'Geneva Convention for the Amelioration of the Condition

\footnotetext{
${ }^{21}$ See Shucksmith (n 8).

${ }^{22} \mathrm{Art} 6(1)$ of the IRCRCM Statutes.

${ }^{23}$ IFRC, 'Constitution: Revised and Adopted by the 16th Session of the General Assembly' (IFRC, Geneva, Switzerland, 20-22 November 2007). www.ifrc.org/Global/Governance/Statutory/ Constitution_revised-en.pdf.

${ }^{24}$ IRCRCM Statutes, Art 6(2).

${ }^{25}$ IFRC, 'Constitution: Revised and Adopted by the 16th Session of the General Assembly' (IFRC, Geneva, Switzerland, 20-22 November 2007). www.ifrc.org/Global/Governance/Statutory/ Constitution_revised-en.pdf.

${ }^{26}$ IRCRCM Statutes, Art 6(3).
} 
of the Wounded and Sick in Armed Forces in the Field' is in force. In addition, under Article 4(3), a National Society must be duly recognised by the legal government of its country based on the Geneva Conventions I, II, III and IV 1949 and of the national legislation as a voluntary aid society, auxiliary to the public authorities in the humanitarian field.

National Societies are made up of staff and volunteers from the community. They design and deliver humanitarian projects based on the needs of the local population. Guinea $^{27}$ Liberia $^{28}$ and Sierra Leone ${ }^{29}$ each has a National Society. The benefit of the National Societies is their unparalleled local knowledge and the fact that they are staffed by local people and volunteers who can best represent and support their communities. Thus, the three constituent components of the Red Cross are 'responders' to humanitarian crises, including infectious diseases. It is theoretically possible to look at the Red Cross response to Ebola in isolation, but international organisations do not act in a vacuum. It is one thing to describe the mandate and activities of one entity, it is another thing entirely to understand how multiple actors interact, coordinate and respond to the outbreak of infectious diseases. This chapter provides an initial overview of the extent to which the WHO, tasked with coordination of response, can 'dictate' to a humanitarian organisation, which existed prior to its conception.

\section{Ebola Outbreak 2014}

Ebola is an infectious disease that originates in bush meat and then spreads from person to person. Once a person is infected, the disease can spread through sweat, tears, mucus, saliva, vomit, diarrhoea, breast milk, urine, blood, and through sexual intercourse. ${ }^{30}$ The 2014 West African outbreak of the disease was the worst to date, culminating in Public Health Emergency of International Concern being declared in August 2014. ${ }^{31}$ The outbreak began in remote rural districts of Guinea and was later reported in Liberia and Sierra Leone.

Some incidences of illness had been reported in November and December 2013, and in late January 2014, local health officials in Guinea investigated unexplained deaths, suspecting cholera. Three days later, a larger investigatory team, including MSF and regional WHO, began work. As the infection spread, it also led to cases

\footnotetext{
${ }^{27}$ http://www.ifrc.org/en/news-and-media/news-stories/africa/guinea/.

${ }^{28} \mathrm{http}$ ://www.ifrc.org/en/what-we-do/where-we-work/africa/liberian-red-cross-society/.

${ }^{29} \mathrm{http} / / / \mathrm{www}$. ifrc.org/en/what-we-do/where-we-work/africa/sierra-leone-red-cross-society/.

${ }^{30}$ Stein (2015).

${ }^{31}$ World Health Organisation, 'WHO Statement on the Meeting of the International Health Regulations Emergency Committee Regarding the 2014 Ebola Outbreak in West Africa', http://www. who.int/mediacentre/news/statements/2014/ebola-20140808/en/; for a more detailed timeline see: Mark Eccleston-Turner \& Scarlett McArdle, 'The Law of Responsibility and the World Health Organisation: A Case Study on the West African Ebola Outbreak’ [-].
} 
in cities, where the risk of the spread of infection was much higher. ${ }^{32}$ By the 1 st February, the infection had spread into Conakry, Guinea's capital and largest city. It was not until the 13th March that the Ministry of Health in Guinea issued its first alert, followed by an investigation from 14 to 25 March. It was during this time, on the 21 March 2014, that the disease was identified as Ebola. Cases were reported in Liberia on 22 March 2014, and it was at this point that the infection could have been deemed to be an international epidemic.

Guinea, Liberia, and Sierra Leone struggled to stop the spread of disease, in part because of resource limitations, lack of knowledge and understanding, cultural practices that facilitated the spread of disease, and in part, as noted above, because of the porous borders. One limitation to the initial response by the state itself is that public health systems in Guinea, Liberia, and Sierra Leone were 'already weakened by protracted conflicts, [and were] struggling to implement measures to contain the virus'. ${ }^{33}$ In addition, as Alasan Senghore writes,

West Africa's cultural, political and geographical context, with porous borders and a mobile population, [had] much to do with the unprecedented scale of [the epidemic]. So has the parlous state of health systems, some in countries not long emerged from conflict. Community distrust—of institutions and agencies—-has certainly had an impact. As a consequence, health information campaigns have struggled. ${ }^{34}$

In brief, state health care systems were not ready for Ebola, and health workers lacked specialised equipment and training. Some succumbed to the disease, while others refused to work for fear of infection. ${ }^{35}$ A lack of available national healthcare facilities, especially primary care services, is an issue for many post-conflict states. ${ }^{36}$ In situations like this, the response of the international community and actors is critical to prevent the spread of the infection. The outbreak required international cooperation to treat those already infected and prevent the spread of infection further. As the WHO and IFRC stated,

[t]he high mortality rates (over 70\% among untreated patients), the exponential escalation of cases in Guinea, Liberia, and Sierra Leone and the potential for the epidemic to spread globally through international travel resulted in a massively scaled and coordinated international response from Emergency Medical Teams. ${ }^{37}$

\footnotetext{
${ }^{32}$ Campbell (2017).

${ }^{33}$ Murray et al. (2014).

${ }^{34}$ Foreword by Alasan Senghore (IFRC Africa Regional Director) in IFRC (2015a).

${ }^{35}$ Ibid.

${ }^{36}$ Concluding Observations of the Committee on Economic, Social and Cultural Rights: Croatia (5 December 2001) UN Doc E/C.12/1/Add.73, para 34; Serbia and Montenegro (23 June 2005) UN Doc E/C.12/1/Add.108, paras 33-36, 60-63; Cambodia (12 June 2009) UN Doc E/C.12/KHM/CO/1, paras 32-33; Democratic Republic of Congo (16 December 2009) UN Doc E/C.12/COD/CO/4, para 34; Afghanistan (7 June 2010) UN Doc E/C.12/AFG/CO/2-4, paras 40-42; CESCR, 'Concluding Observations on the Second to Fourth Periodic Report of Rwanda, adopted by the Committee at its Fiftieth Session (29 April-17 May 2013)' (10 June 2013) UN Doc E/C.12/RWA/CO/2-4, para 25. ${ }^{37} \mathrm{WHO}$ and IFRC (2017b).
} 
The speed of response was much faster in Nigeria, where the first case was confirmed in July 2014; health officials immediately repurposed technologies and infrastructures from the WHO and other partners to find and track potential chains of transmission of Ebola. ${ }^{38}$ The end of transmission in Liberia, and the 'effective end of the outbreak in West Africa', was marked on the 14th January 2016. ${ }^{39}$

\section{The Role of the WHO in Coordinating a Medical Humanitarian Response}

Infectious diseases did not come within the normative confines of international law until the mid-nineteenth century. ${ }^{40}$ International law is a consensual system whereby states agree to be bound by treaties or customs that they freely enter into with other states. ${ }^{41}$ There are two inherent weaknesses in international law when it comes to infectious diseases. The first is consent by states to external actors being present; the second is that, as infectious diseases do not respect state borders, states and organisations must collaborate and cooperate to prevent, respond to and recover from infection. Sovereignty is paramount to states and therefore any global intervention must be consented to by the state. ${ }^{42}$

The International Sanitary Conferences were convened to meet the need for agreeing quarantine procedures to prevent the spread of diseases, particularly cholera, without unduly disrupting rapidly growing international trade. ${ }^{43}$ In 1903 , the first international organisation dedicated to health was created. Fidler argues that, at the time, the international legal regime had three pillars: (1) duties to notify other States of outbreaks of specified diseases, (2) limits on the measures other states could take against ships and aircraft coming from states experiencing disease outbreaks, and (3) involvement of an international organisation dedicated to health. ${ }^{44}$ The international legal framework that facilitates the provision of healthcare during outbreaks of disease is complex and refers to a multitude of actors that can enter into partnerships, forge relationships to oversee certain activities, or coordinate response on the ground.

In the aftermath of the Second World War, the focus of the UN was peace and security. The foundation of the WHO in 1948 recognised the transboundary nature of disease and envisaged an international support system for the prevention of the spread of disease coordinated by the WHO. The Red Cross, at the same time, was drafting

\footnotetext{
${ }^{38}$ See WHO Media Centre; Brookings Edu (2014).

${ }^{39}$ WHO, http://www.who.int/mediacentre/news/releases/2016/ebola-zero-liberia/en/.

${ }^{40}$ Aginam (2002).

${ }^{41}$ Art 38 (1) Statutes of the ICJ; See also International Sanitary Convention 1851, 1859, 1866, 1874, 1881, 1885, 1892, 1893, 1894 and 1897. Four treaties 1892, 1893, 1894 and 1897. See Howard-Jones (1950) in Fidler (1997).

${ }^{42}$ Harman (2012) 28.

${ }^{43}$ Clift (2013a).

${ }^{44}$ Fidler (2000).
} 
the Geneva Conventions, which foresaw conflict and insecurity across boundaries and, to a lesser extent, within sovereign states. Nevertheless, the mandate provided to the Red Cross by the Geneva Conventions envisaged a humanitarian presence at the consent of sovereign states and, furthermore, created a system whereby there was a potentially permanent Red Cross presence in every state. Official relations were established between the WHO and the League of Red Cross Societies, the previous name of the IFRC, in $1948 .{ }^{45}$

What these parallel systems mean today is that it is unclear which actor has the ultimate authority. Can the WHO, as a specialised agency of the UN, coordinate an international institution with its own mandate provided by international agreement? ${ }^{46}$ It is all very well to think about the relationship between the WHO and NGOs active in health and humanitarianism, but the Red Cross is different from such entities. What is the more nuanced relationship between the WHO and the Red Cross? Is it possible to determine the power and authority of each in the provision of health care and the prevention of the spread of infectious disease?

In 1951, the WHO adopted the International Sanitary Regulations, which became the International Health Regulations in 1969. The IHRs represent the 'only international health agreement on communicable diseases that is binding on Member States [of the WHO]'. ${ }^{47}$ The World Health Assembly adopted the revised IHRs on 23 May 2005 at a time when 'public health, security, and democracy became intertwined' ${ }^{48}$ States recognised that they needed to act together to stop the spread of infectious diseases, as 'states could better protect their populations through early detection of health hazards and containment at their source'. ${ }^{49}$ Presently, the 2005 International Health Regulations are the most up to date international legal rules on the control of infectious diseases, and provide a unified code for infectious disease control.

The overall purposes of the IHRs are to prevent, protect against, control and provide a public health response to the international spread of disease... commensurate with and restricted to public health risks, and which avoid unnecessary interference with international traffic and trade, ${ }^{50}$ and to 'ensure maximum protection against the international spread of disease with minimum interference with world traffic.' 51 The IHRs have 'universal application for the protection of all people of the world' ${ }^{52}$ They are coordinated by the World Health Organisation (WHO); the Constitution sets out twenty-two functions for the WHO, which cover almost every conceivable activity linked to the promotion of health, ${ }^{53}$ and states that the WHO is a 'directing

\footnotetext{
${ }^{45}$ XVIIth International Red Cross Conference, Report by the Director-General (7 September 1948, $\mathrm{EB} 2 / 38)$.

${ }^{46}$ See Art 14(2) International Health Regulations 2005.

${ }^{47}$ WHO (1996).

${ }^{48}$ Gostin (2014).

${ }^{49}$ Ibid.

${ }^{50}$ Art 2 IHR 2005.

${ }^{51}$ WHO (1983).

${ }^{52}$ Art 3 IHR 2005.

${ }^{53}$ Clift (2013b).
} 
and coordinating authority for health within the United Nations system' ${ }^{54}$ These words are key to our understanding and analysis of the WHO and the response to the West Africa Ebola outbreak.

The IHRs stipulate that health measures must be applied in a transparent and non-discriminatory manner. ${ }^{55}$ States must consider a quarantined individual's gender, as well as sociocultural, ethnic, or religious concerns, and provide adequate food, water, accommodation, baggage protection, medical treatment, and communication. ${ }^{56}$ Fidler states that 'although the IHR are technically binding rules, most States view them as merely recommendations rather than real obligations' ${ }^{57}$ Nevertheless, in some ways soft law, argues Dupuy, can be 'seen not only as a description of a type of norm but also a process that seeks to build cooperation and consensus in achieving certain objectives' ${ }^{58}$ States bordering the 'infected' State will want to stop the spread of disease, so there are questions over who or what should support the intervention by third States, international organisations, or NGOs. In a global age, however, the perceived threat and potential responders go beyond neighbouring states. Globalisation and increased travel and trade within and between countries have resulted in the rapid spread of disease. This was typified by the rapid spread of Severe Acute Respiratory Syndrome (SARS) across three continents within weeks in $2003^{59}$ and by pandemic $2009-\mathrm{H} 1 \mathrm{~N} 1$ influenza. ${ }^{60}$ There is, therefore, an international legal framework including the Constitution of the WHO and the IHRs that seeks to provide an adequate response to outbreaks of infectious diseases. Overall, the IHRs aim to provide global health security but this relies on informational and communication channels being utilised to pass correct information from local healthcare providers to national bodies and then on to the WHO.

Despite the clear role and mandate of the WHO, it is a frequently-criticised entity. Its internal governance structures are argued to be in need of reform. It has been argued that the Ebola outbreak of 2014 served to highlight the inadequacies of the WHO. ${ }^{61}$ Harman, for example, criticised the WHO for failing to keep up with the 'mission creep' of other institutions. She argued that the WHO needed to build partnerships with other institutions as 'partnerships are integral to its operations', but highlighted

\footnotetext{
${ }^{54}$ Clift (2013c).

${ }^{55}$ Art 42 IHR 2005.

${ }^{56}$ Art 32 IHR 2005; See also Arts 23 and 45 IHR 2005.

${ }^{57}$ Fidler (n 41) 63.

${ }^{58}$ Dupuy (1991) in Fidler (n 41) 63.

${ }^{59}$ Skowronski et al. (2005).

${ }^{60}$ Bajardi et al. (2011).

${ }^{61}$ Mackey (2016); WHO Interim Assessment panel established by the WHO Executive Board (Interim Panel), Report of the Ebola Interim Assessment Panel, http://www.who.int/csr/resources/ publications/ebola/report-by-panel.pdf; Moon et al. (2015); Commission on a Global Health Risk Framework for the Future (CGHRF) convened by the U.S. National Academy of Medicine (formerly the Institute of Medicine) 'The Neglected Dimension of Global Security: A framework to counter infectious disease crises' (the National Academies Press 2016); Report of the High-Level Panel on the Global Response to Health Crises, 'Protecting Humanity from Future Health Crises' (25 January 2016).
} 
the fact that the WHO has focused on working with States and other UN agencies ${ }^{62}$ : 'Institutions such as the ICRC have greater presence within the meetings of the WHO than governments from small developing countries'. ${ }^{63}$

The criticisms levied echo many made over the past 15 years, whereby a number of infectious disease outbreaks have highlighted the limitations of the WHO mandate and practice, including SARS 2002, H1N1 2009, MERS 2013, H5N1 2005, and, most recently, the 2014 West African Ebola outbreak. ${ }^{64}$ Moreover, if we think about the UN approach as one that is now securitising the idea of global health, then this is an extension of the idea that health is a 'global public good'. ${ }^{65}$ Indeed, global health has, for a long time, been linked to 'wider processes of international politics' and 'political economy' ${ }^{66}$ The problem with this, argued Harman, is that the WHO might be thwarted by 'member state sovereignty and the trumping of economic issues such as trade over global health concerns' ${ }^{67}$ If we consider the above critique of the WHO, then the West African Ebola outbreak was a pivotal episode. It was an opportunity to demonstrate is capabilities and response to a transnational disease outbreak.

\section{WHO and Ebola 2014-2016}

'On 25 March, 2014 the WHO Global Emergency Management Team had graded the outbreak as a Level 2 emergency and were coordinating daily conferences on risk assessment, operational planning and review between Ministry of Health officials in of Guinea, Sierra Leone, and Liberia, the WHO country offices, the WHO Inter-country support teams (IST) of West Africa, WHO headquarters and the WHO African regional office (WHO AFRO)'. ${ }^{68}$ The WHO declared the Ebola outbreak a 'public health emergency of international concern' (PHEIC) under the IHR on the 8th August 2014. ${ }^{69}$ The WHO published materials on the evolution of the Ebola outbreak, then it chronicled its spread from earlier than 8th August. ${ }^{70}$ It suggested, in its 'Statement on the 1st Meeting of the IHR Emergency Committee on the 2014 Ebola outbreak in west Africa', increasing oversight and support at the requests of the presidents of Guinea, Sierra Leone, and Liberia, culminating in the WHO

\footnotetext{
${ }^{62}$ Harman (n 42) 40.

${ }^{63}$ Harman (n 42) 56.

${ }^{64}$ Wibulpolprasert and Chowdhury (2016), Mackey and Liang (2012), Baker and Fidler (2006), Siedner (2015), Gostin (2015), Garrett (2015), Kupferschmidt (2015), and Checchi et al. (2016).

${ }^{65}$ Harman (n 42) 33.

${ }^{66}$ Harman (n 42) 34.

${ }^{67}$ Harman (n 42) 38.

${ }^{68} \mathrm{WHO}$ and IFRC (2017c).

${ }^{69}$ Art 12 IHR gives WHO Director-General the authority to determine whether an event constitutes PHEIC.

${ }^{70}$ See the Ebola Response Modelling Tool designed by Centers for Disease Control and Prevention which estimated the potential number of future Ebola cases, https://www.cdc.gov/media/releases/ 2014/s0923-ebola-model-factsheet.html (23 September 2014).
} 
PHEIC of 8th August. ${ }^{71}$ It could be suggested that that this delay is indicative of a weak international framework for the response to international epidemics, but the alternative argument is that the WHO was involved through its regional organs. In addition, indeed, 'the WHO's coordinating role in developing the Ebola vaccine also highlights one of its unique benefits-no other body has the convening power of this intergovernmental agency, which can rapidly bring together scientists, industry, regulators and national public-health officials when needed'. ${ }^{72}$

Though '[o]nly the government of [an] affected country can make the decision whether to accept or reject EMTs (Emergency Medical Teams) in non-conflict disasters' ${ }^{73}$ it is recognised, however, that there is a multitude of complex reasons as to why the treatment delivered during a pandemic may not be the highest standard available, most notably that many states who bear the greatest burden of infectious diseases are the least well positioned to respond to outbreaks. ${ }^{74}$ In its joint 2017 publication, 'The Regulation and Management of International Emergency Medical Teams', the WHO and IFRC noted that

\begin{abstract}
[t]he tasking of teams responding to the EVD outbreak followed a 4-step process. Firstly, teams either stepped forward and offered their assistance (very few actually did this), or were directly approached by the WHO EMT initiative. Secondly, local needs were assessed and as far as possible met by the WHO and its partners. Thirdly, the WHO helped channel the offers of assistance to the respective Ministries of Health. Fourthly, tasking to an ETC location was undertaken by the Ministry of Health with support from the WHO EMT coordination cell. Importantly, this process could only begin once there were sufficient numbers of EMTs offering their assistance; therefore the majority of steps 3 and 4 did not take place until November and December 2014. The complexity of a three-country response to Ebola was further compounded when individual donor countries supported specific countries that were affected, rather than all three (e.g. the US supported Liberia, the UK supported Sierra Leone, and France supported Guinea). ${ }^{75}$
\end{abstract}

If we consider the importance of travel and trade to many developing economies, disease emergence can have a catastrophic effect. Gostin suggests that in the past, this has led to 'a vicious cycle of disease emergence, failure to report, and economic ramifications'. ${ }^{76}$ It doesn't appear from the existing literature and reports concerning Ebola that the lack of reporting in Guinea was down to fear of economic ramifications, but rather owing to incorrect diagnosis and insufficient public health infrastructure. ${ }^{77}$

\footnotetext{
${ }^{71}$ WHO Statement, 'Statement on the 1st meeting of the IHR Emergency Committee on the 2014 Ebola outbreak in West Africa' (8 August 2014), http://www.who.int/mediacentre/news/statements/ 2014/ebola-20140808/en/.

${ }^{72} \mathrm{https}$ ://www.nature.com/news/the-time-is-ripe-to-reform-the-world-health-organisation-1. 21394.

${ }^{73} \mathrm{WHO}$ and IFRC (2017d).

${ }^{74}$ Wilson et al. (2010); Report by the Director-General, 'Report of the Review Committee on the Functioning of the International Health Regulations (2005) in relation to Pandemic (H1N1) 2009: Implementation of the International Health Regulations (2005)' 64th World Health Assembly A64/10, 11 May 2011.

${ }^{75} \mathrm{WHO}$ and IFRC (2017e).

${ }^{76}$ Gostin (n 48) 178 .

${ }^{77}$ Shoman et al. (2017).
} 
The more critical comments were levied at the delay by the WHO responding to Ebola. It took over eight months from the first case to the WHO declaration. The Director-General of WHO called for UN full capacity to help with the response. ${ }^{78}$

On the 18th September 2014, the UN Security Council, for the first time, declared a disease outbreak as a threat to international peace and security. This was the first time they had used 'declaratory' language. ${ }^{79}$ The securitisation of disease at the UNSC is not without precedent-the Security Council concerned itself with AIDS, although this took 19 years, and Article 39 of the UN Charter was not used. ${ }^{80}$ Perhaps what is more critical when looking at this gap between identification of the disease and UN response is the context. In the context of this paper, I would contend that the addition of other UN agencies, beyond WHO, makes the coordination and response even more confusing. In addition to the coordination role of the $\mathrm{WHO}$, the UN has other mechanisms to respond to global health crises.

On 20 September UN Secretary-General Ban Ki-Moon established the UN Mission for Ebola Emergency Response (UNMEER). ${ }^{81}$ The mission ran between 19 September 2014 and 31 July 2015, after which the WHO took the lead of the oversight of the UN's emergency response. Security Council Resolution 2177 'represents the most cogent recognition to date of a "non-traditional threat to international peace and security", 82 The UN Secretary-General deployed the UN Emergency Health Mission to 'harness the capabilities and competences of all relevant United Nations actors under a unified operational structure'. ${ }^{83}$ Critically for this paper, Security Council Resolution 2177 refers to the IFRC as a first line responder. ${ }^{84}$

\footnotetext{
${ }^{78}$ WHO (2015).

${ }^{79}$ United Nations Security Council resolution 1308, adopted unanimously on 17 July 2000, was the first resolution to address the impact of HIV/AIDS worldwide. The UNSC stated that 'the HIV/AIDS pandemic, if unchecked, may pose a risk to stability and security' and held a meeting in 2000 on "The situation in Africa: the impact of AIDS on peace and security in Africa".

${ }^{80}$ On 5 June 1981, the US Centers for Disease Control and Prevention (CDC) published a Morbidity and Mortality Weekly Report (MMWR). It described cases of a rare lung infection, Pneumocystis carinii pneumonia (PCP), in five young, previously healthy, gay men in Los Angeles. It is the first official reporting of what became known as the AIDS epidemic.

${ }^{81}$ General Assembly Resolution 69/1 (2014); Security Council Resolution 2177 (2014).

${ }^{82}$ UN Secretary General, Statement by Secretary-General on the establishment of the United Nations Mission for Ebola Emergency Response (UNMEER) (19 September 2014); Security Council Resolution 2177 (18 September 2014); United Nations General Assembly Resolution 69/1 (2014); see also 'Introductory Note to WHO and UN Documents on the Ebola Outbreak in West Africa' (2015) 54 International Legal Materials 535-560.

${ }^{83}$ UN Secretary General, 'Identical Letters Dated 17 September 2014 from the Secretary-General Addressed to the President of the General Assembly and the President of the Security Council' UN Doc A/69/389- S/2014/679 (18 September 2014) 2.

${ }^{84}$ Security Council Resolution 2177 (18 September 2014) preamble.
} 


\section{The UN Relationship with Other Actors, Including the IFRC}

There are several actors on the international stage with their own legal mandate to respond to infectious disease outbreaks. The WHO, UNMEER, and the Red Cross undertook several actions, established working groups and committees, and coordinated on the ground to try to stop the spread of infection and to treat those who had already succumbed. They relied on partnerships with each other and the governments of each state. The working relationships were essential as the outbreak was too large in scale for one organisation, state or local community to respond to alone. The necessity of expertise, resources, technical assistance, and personnel required a coordinated and sustained approach.

The international legal framework that facilitates the provision of healthcare during outbreaks of disease is complex and involves a multitude of actors that can enter into partnerships, forge relationships to oversee certain activities, or coordinate response on the ground. The IFRC is a 'partner' of the WHO in disaster response and has established 'formal agreements' in several contexts to facilitate its presence and role in specific situations on the ground. ${ }^{85}$ It also has an active agreement, a Memorandum of Understanding, with the South-East Asia Regional Office of the World Health Organisation (SEARO). ${ }^{86}$

The IHRs do not specifically mention the National Red Cross and Red Crescent Societies but the IFRC is named as one of the international organisations with which the WHO must co-operate in implementing the IHRs. ${ }^{87}$ The IFRC and National Societies work with governments on humanitarian protection and assistance issues and it is one of the aims of the IFRC to help governments prepare its legislation and resources for disaster situations. In fact, part of the role of the National Societies is to make the governments aware of changes in legislation that may be necessary to implement the IHR. At the national level, therefore, the National Societies can help to improve pandemic preparedness and response, which in turn can prevent the spread of disease, thus protecting international public health.

Importantly, in addition to the roles prescribed by its own mandate, and its direct relationship with the WHO, the IFRC has a standing invitation to participate in the Inter-Agency Standing Committee (IASC) Health Cluster under the leadership of WHO. The role of the IASC is to "empower humanitarian country teams to better

\footnotetext{
${ }^{85}$ The IFRC has a working agreement with the WHO for disaster response and it also has an agreement with WHO and South-East Asia Regional Office. See also IFRC, 'Setting up a national disaster preparedness and response mechanism'. www.ifrc.org/Files/160282/175200_Setting-upnational-dpr-mechanism_EN.pdf.

${ }^{86}$ Memorandum of Understanding (MoU) with the South-East Asia Regional Office of the World Health Organisation (SEARO): covers public health, non-remunerated blood donation, health in disaster preparedness and emergency response, and collaboration in other health related areas. Countries covered are Bangladesh, Bhutan, DPRK, India, Indonesia, Maldives, Myanmar, Nepal, Sri Lanka, Thailand and Timor-Leste.
}

${ }^{87}$ Art 14(1) IHR 2005. 
address the health aspects and crises'. ${ }^{88}$ The IASC was established in June 1992 following General Assembly Resolution 46/182. Its role is to 'serve as the primary mechanism for inter-agency coordination relating to humanitarian assistance in response to complex and major emergencies under the leadership of the Emergency Relief Coordinator'. The Red Cross is a standalone humanitarian organisation and partner of the WHO/ IASC at the international level. It can interpret its own mandate and support or be called upon to support the work of other international actors. In addition, its National Societies provide it with an existing local presence, which aids in the provision of humanitarian relief during times of conflict and in the event of a disaster. Nevertheless, overall, the picture is quite confusing as to who is lead agent, whether the IFRC is an autonomous actor, and whether the IFRC coordinates successfully with other agencies. The Red Cross, in some ways, escapes the political and economic hindrances of the international stage and can respond to outbreaks of disease from the 'bottom-up'. The mandate of the IFRC allows it to respond to public health emergencies and it also has a separate role in disaster relief and disaster risk reduction.

The WHO is meant to coordinate, but given the range of global health NGOs on the international stage, there are many other actors with the mandate and resources to react to the outbreak of disease. The UN is not the only organisation that States will form agreements with, as actors such as the Red Cross have the capacity to negotiate and enter into agreements too. Moreover, the UN does not always have the operational capacity to respond adequately. The dilemma facing responders is whether there should be one central coordinating body for the entire response, perhaps the WHO, or whether they are each within their rights to do what they want and help whom they want. In this light, the IHRs might, by necessity, have to be renegotiated to include specific mention of a wider set of institutions. However, perhaps doing so might put more operational pressure on NGOs to respond to all outbreaks of disease rather than making choices.

The overall argument in this chapter, taking this all into account, is that there are more actors ready and willing to respond to international health issues than are within the ability of the WHO to coordinate presently. That said, it is not the sole purpose of this chapter to criticise the WHO; its purpose is to add to the literature to show that the Red Cross has an international legal mandate to provide health care during the outbreak of infectious disease. In addition, although, in some instances, it might make sense for the IFRC and National Societies to work with the WHO, on its own terms, they cannot and will not wholly subjected to WHO coordination. The Red Cross, critically, also has the scope through its organisational structure and International Conference to increase its competences over time to continue its ability to respond to health crises.

${ }^{88}$ IASC, https://interagencystandingcommittee.org/. 


\section{The IFRC Response}

As stated above, the IFRC is one of the actors involved in the response to infectious diseases. The IFRC was founded in 1919 in Paris after the First World War to help National Societies. ${ }^{89}$ Its first objective was to improve the health of people who had suffered during the four years of the war. The Red Cross provides a counterpart to the more state interest focused international system, which includes the WHO and IHR. The Red Cross was created to provide humanitarian protection and assistance directly to those in need. The Red Cross has an international mandate to provide health care to civilians and combatants during conflict and disaster situations. ${ }^{90}$ Critically, the Red Cross was designed to reach communities and people in need. It is still subject to the consent of states, whether that is through the Geneva Conventions, Statutes of the Red Cross and Red Crescent Movement, and Headquarters agreements. However, its principles mean that is stays in favour with governments and is able to stay in countries for long periods of time. The ICRC, for example, often maintains a presence long after an identifiable armed conflict has ended. In this way, its reputation and humanitarian mandate set is apart from other organisations and NGOs. In circumstances where, for whatever reason, states decide that they no longer wish for the Red Cross to work within its territory, states might, should they be so inclined, refuse to grant visas to delegates, or perhaps even revoke visas, but this is unlikely. The Red Cross is renowned for its discretion and states trust that the organisation will work without exposing its inability to provide for its own population.

The IFRC is well placed to understand and respond directly to the needs of the people on the ground without being swayed by the economic, trade and tourist considerations that may preclude the state reporting to the WHO. Its principle of confidentiality, working with National Societies that understand the local context, and working on the ground to help and support those in need, keeps it in favour with both the government and local population. However, this did not prevent local fears and cultural requirements stopping the IFRC from doing its work during the 2014 West African Ebola outbreak.

The IFRC response was coordinated from late March 2014 when the Ministry of Health in Guinea had raised the alarm, even though the WHO did not declare a PHEIC until the 8th August the same year. For the Red Cross, it meant training 10,000 volunteers in Ebola response; the IFRC also supported emergency operations in Guinea, Liberia, and Sierra Leone, which targeted 23 million people. ${ }^{91}$ As argued above, the IFRC has the mandate to provide health care to citizens and is well placed on the ground to do so quickly. It is, however, undertaking such action within a multi-agency response, including WHO via the IHRs, MSF, and the military and so

\footnotetext{
${ }^{89}$ The original organisation was called the League of Red Cross Societies until 1983 when it became the League of Red Cross and Red Crescent Societies until 1991. Since 1991 it has been called the International Federation of the Red Cross.

${ }^{90}$ Statutes of the Red Cross and Red Crescent Movement, preamble, principle of humanity, art 3(2) National Red Cross and Red Crescent Societies, and art 6(4)(f) IFRC.

${ }^{91}$ Senghore (n 34).
} 
on. This chapter shows that the IFRC is simultaneously a leader, and directed by other entities, in its response to infectious disease.

The IFRC deployed a Field Assessment Coordination Team to Guinea that included an infectious disease specialist from the French Red Cross Society and a psychosocial support delegate. The IFRC was already on the ground in Guinea working through a cholera epidemic and measles outbreak. ${ }^{92}$ However, as symptoms of Ebola are similar to cholera, it was difficult for the IFRC to recognise and, therefore, announce that Ebola was spreading. Ebola outbreaks have occurred previously but the IFRC documented that this outbreak presented several unique challenges. Firstly, it affected communities and governments that were 'new to the disease' and did not have the appropriate equipment, facilities and procedures in place. Secondly, in some areas people believed that the people spraying disinfectant were the ones spreading the disease, which caused violent, sometimes deadly, reactions. In addition, some cultural practices, including burial practices, facilitated the spread of the disease. ${ }^{93}$ Finally, the outbreak occurred in an area where three states-Guinea, Sierra Leone and Liberia-have borders, and 'the porous nature of the borders of the countries involved, regional trade, interconnectedness of families and fluid population movement both within and between the affected countries [was] key to the geographical spread' ${ }^{94}$

In terms of the IFRC response to Ebola, Alasan Senghore stated that

[t]he Red Cross and Red Crescent is community-based. Our people were there before the outbreak and they will remain there when it is over and most of the other responders have gone. It is what we have always been about, and our volunteers will continue to support communities as they recover, not only in relation to Ebola but also the parallel health and humanitarian challenges. ${ }^{95}$

The specifics of the IFRC response to the 2014 West African Ebola outbreak show how a humanitarian organisation with a local base can act quickly in response to an infection. During the outbreak of Ebola, the IFRC suggested that the Ebola outbreak was an instance of a public health response within its disaster management systems. ${ }^{96}$ Usually when there is a disaster the situation on the ground improves from day one. The teams respond, assess and produce a plan of action for relief, recovery and build back better. ${ }^{97}$ However, with Ebola, the situation worsened over time. ${ }^{98}$

\footnotetext{
${ }^{92}$ IFRC (2014d).

${ }^{93}$ Tiffany et al. (2017).

${ }^{94}$ IFRC (2015b).

${ }^{95}$ Senghore (n 34).

${ }^{96}$ International Red Cross and Red Crescent Movement, 'Ebola Strategic Framework' (January 2015).

${ }^{97}$ Build Back Better is defined as "The use of the recovery, rehabilitation and reconstruction phases after a disaster to increase the resilience of nations and communities through integrating disaster risk reduction measures into the restoration of physical infrastructure and societal systems, and into the revitalisation of livelihoods, economies and the environment." See United Nations Office for Disaster Risk Reduction (UNISDR), 'Build Back Better in recovery, rehabilitation and reconstruction' (2017 Consultative Version). http://www.unisdr.org/files/53213_bbb.pdf.

${ }^{98}$ IFRC (2015c).
} 
The political and cultural resistance by states to acknowledging the outbreak delayed official recognition. ${ }^{99}$ In this situation, the IFRC was an essential organisation on the ground, not least because of its local volunteers who possessed the local knowledge and expertise necessary to work with the local communities, as 'no other organisation has such a resource and harnessing it is key'. ${ }^{100}$ This is part of the uniqueness of the IFRC. In addition, it is clear that the IFRC is an essential institution on the ground. Its mandate, reputation and operations capability set it apart from the WHO, which focuses on coordination. The IFRC is able to coordinate from Geneva to the state level and then reach individual communities through its network of National Societies. This infrastructure is unique to the IRCRCM, and critical for an effective response to an infectious disease outbreak.

The international community recognised Ebola as a threat to international peace and security through UN Security Council resolution 2177 and the WHO used its most extreme category for the outbreak; but for the most part the international community was slow to act. The IFRC, however, mobilised quickly and effectively. The IFRC was guided by several humanitarian policy guidelines to ensure that the Ebola emergency response met the necessary standards. ${ }^{101}$ The Red Cross focused on education and awareness raising, providing psychosocial support and safe burial practices. ${ }^{102}$

The IFRC response was built on five pillars including surveillance and contact tracing, community engagement, safe and dignified burials and disinfection, psychosocial report, and case management. ${ }^{103}$ The IFRC launched six emergency appeals to respond to Ebola outbreaks in Guinea, Liberia, Sierra Leone, Nigeria, and Senegal. ${ }^{104}$ Smaller preparedness and response operations were financed by the IFRC Disaster Response Emergency Fund (DREF) in Mali, Cote d'Ivoire, Cameroon, Togo, Benin, Central African Republic, Chad, Gambia, Kenya, Guinea Bissau and Ethiopia. ${ }^{105}$ There were an anticipated five outcomes of the IFRC Ebola Strategic Framework, including stopping the epidemic; ensuring that the National Societies have better Ebola preparedness and stronger long-term capacities; ensuring the good coordination of IFRC operations; facilitating safe and dignified burials by all actors; and the recovery of community life and livelihoods. ${ }^{106}$ 'The overall IFRC response [was] coordinated from the IFRC Ebola coordination centre in Conakry, Guinea where

\footnotetext{
${ }^{99}$ Senghore (n 34).

${ }^{100}$ IFRC, 'Ending Ebola' 8; See also IFRC (2017).

${ }^{101}$ Principles and Rules for Red Cross and Red Crescent Humanitarian Assistance (IFRC 2013), http://www.ifrc.org/Global/Documents/Secretariat/Accountability/Principles\%20Rules\% 20for\%20Red\%20Cross\%20Red\%20Crescent\%20Humanitarian\%20Assistance.pdf; IFRC Disaster Preparedness Policy, http://www.ifrc.org/Global/Governance/Policies/disaster-policy-en.pdf; Emergency Response Policy and Sphere Standards, The Sphere Hanbook (New edn 6 November 2018), http://www.spherestandards.org/.

${ }^{102}$ American Red Cross (2014).

${ }^{103}$ See the IFRC Emergency Appeals for Guinea, Sierra Leone and Liberia.

${ }^{104}$ See www.ifrc.org.

${ }^{105}$ See IFRC (2015c).

${ }^{106}$ International Red Cross and Red Crescent Movement, 'Ebola Strategic Framework' (January 2015).
} 
the IFRC head of emergency operation leads a programme support team in order to maintain a coordinated response in multiple countries following the same response strategy but adapted to specific contexts and National Society capacity, role and mandate'. ${ }^{107}$ The IFRC Africa Regional Director stated that:

What the world must understand is that West Africa's epidemic has been about more than
Ebola itself. It has shown how weak health systems with insufficient health workers unable
to respond to emerging needs can spiral into a severe humanitarian crisis, especially when
international response is slow. Whether it be in Ebola affected areas or anywhere else, support
for health and community systems is central to ensuring universal health access, and that is
the cornerstone of resilient communities and sustainable development. ${ }^{108}$

Critically, Guinea, Sierra Leone and Liberia are places where governments cannot deliver basic services to most of their population. Across Guinea, Liberia and Sierra Leone, the IFRC works to implement the five pillars, taking the lead on Safe and Dignified Burials. They partner with the Ministry of Health, WHO, World Food Programme, UNICEF, MSF and other regional and international organisations to deliver the five pillars. Other organisations and departments take the lead on other pillars, but with support from the IFRC. It is beyond the scope of this chapter to describe each partnership and 'hierarchy' in the Ebola response, but, as we know from its relationships with other institutions described above, the IFRC does not act alone. The IFRC is well placed to engage with the local communities and the reports from Guinea, Sierra Leone and Liberia show the importance of such engagement. It was noted early in this chapter that superstition and fear prevented a number of infected people from coming forward, made communities suspicious of external actors, and in many cases actually quickened the spread of disease through failure to take the proper steps to prevent the spread of disease.

If we look at the three key states responding to the Ebola outbreak as the number of cases and geographical spread of Ebola increased in Guinea, the IFRC reported that

[t]he major factors that continue to quicken the spread of the virus include: poor understanding of the disease; inadequate communication; misconceptions and fear among affected communities; lack of adherence to strict protocols by healthcare workers dealing with [Ebola]; and limited responding capacities. ${ }^{109}$

These factors were present, as noted above, in other states affected by Ebola. The IFRC does not have a representation in Guinea but it does participate in all national and other coordination meetings with the Guinea Red Cross (GRC). The IFRC established an Ebola Management Unit in Conakry. The GRC is focused on four of the five pillars identified above, including social mobilisation, safe and dignified burials and disinfection of houses, psychosocial support, and case management and treatment. ${ }^{110}$

\footnotetext{
${ }^{107}$ IFRC, 'Emergency Appeal Sierra Leone: Ebola Virus Disease', http://www.ifrc.org/en/ publications-and-reports/appeals $/$ ? $=43 \& z 0=S P 1$.

${ }^{108}$ Senghore (n 34).

${ }^{109}$ IFRC (2014a).

${ }^{110}$ Ibid.
} 
The IFRC accepted a request by the United Nations Mission for Ebola Emergency Response (UNMEER) to take a leading role in the safe and dignified burials, disinfection of households and contaminated areas, as well as the transportation of sick patients in certain regions.

In Liberia, the Liberia Red Cross Society, with support of the IFRC operations team, increased the number of volunteers active. Its focus, as in Guinea, was the safe and dignified burials of those who were suspected to have died of Ebolaa key task required in order to reduce transmission. ${ }^{111}$ In Sierra Leone, the first announcement of cases were accompanied by reports that six of the initial eight suspected and confirmed cases had refused to be placed in isolation and had gone into hiding. There were also reports that Ministry of Health and Sanitation officials had been subjected to aggression in the communities they visited. As a result, early attempts to control the outbreak were unsuccessful. ${ }^{112}$ Finally, the IFRC established a field base of operations in Sierra Leone after the outbreak. It coordinates the same projects as in Guinea, namely social mobilisation, surveillance and contact tracing, psychosocial support, dead body management, coordination, and case management.

\section{Conclusion}

Almost 20 years ago, Fidler remarked that disease needs a complete international legal regime, as 'infectious diseases render borders impotent and undermine a government's ability to protect public health'. ${ }^{113}$ It is common sense that an infectious disease will spread amongst communities and populations, regardless of state borders. When people succumb to disease, they need access to health care that will cure them or, at the very least, ease their suffering. States have the primary obligation to provide such through national health care systems, but there is no universal standard for this. When an infectious disease affects the human population and the State is unable to stop its spread, there is a number of actors on the international stage with the mandate to react and protect people. To this end, international law provides a global legal framework to regulate and coordinate the international response to infectious diseases, including through the mandate of the International Red Cross and Red Crescent Movement (IRCRCM) and the Constitution of the WHO. Of course, any response to infectious disease needs to be bespoke to the disease but there exist a number of international laws and international institutions to provide global mechanisms by which external actors, States and organisations, can support States threatened by the spread of disease.

\footnotetext{
${ }^{111}$ IFRC (2014b).

${ }^{112}$ IFRC (2014c).

${ }^{113}$ Fidler (1999).
} 
Despite international efforts to coordinate humanitarian responses, whether in relation to armed conflicts or disasters, the United Nations Secretary-General's decision to convene a High-Level Panel on the Global Response to Health Crises suggests that new ground needs to be broken in the future coordination of humanitarian responses to infectious diseases. ${ }^{114}$ Similarly, Strategic Aim 1 of the IFRC's Strategy 2020 is to "save lives, protect livelihoods, and strengthen recovery from disasters and crises"115; and the WHO's objective of "the attainment by all people of the highest possible level of health" 116 as well as its objective in disasters and emergencies to "reduce the consequences the event may have on world health and its social and economic implications", shows the ambition of the WHO to respond better to infectious disease in the future.

Ultimately, this chapter has shown the nuanced and complex relationship between the Red Cross Movement and the WHO. As two actors with international mandates concerning health, they have very different roles. The international community should not be aiming for an ultimate coordinating body to oversee the entire response as organisations have grown up independently of one another and have unique and established relationships with the states and communities that they may serve. Of course, on the international stage, delegates may converse, build relationships, discuss operations, but that it not to say that the best practice would come from an ultimate authority dictating the actions of all possible responders. This is particularly the case with the IFRC and National Societies which have built and nurtured relationships with States and each other for decades in order to develop institutional best practice. The autonomy of the Red Cross to react to an outbreak should be respected and, where beneficial to both the WHO and the Red Cross, it may be part of a multi-institutional operation or response.

\section{References}

Aginam O (2002) International law and communicable diseases. Bull World Health Organ 80:946 American Red Cross (2014) American Red Cross supports Ebola response in West Africa, 19 Aug 2014. http://www.redcross.org/news/press-release/American-Red-Cross-SupportsEbolaResponse-in-West-Africa. Accessed 23 Jul 2015

Bajardi P et al (2011) Human mobility networks, travel restrictions, and the global spread of 2009 H1N1 pandemic. PLoS ONE 6(1):e16591

Baker MG, Fidler D (2006) Global public health surveillance under new international health regulations. Emerg Infect Dis 12:1058-1065

\footnotetext{
${ }^{114}$ Report of the High-level Panel on the Global Response to Health Crises, 'Protecting Humanity from Future Health Crises' (25 January 2016).

${ }^{115}$ See Resolution 7 of the 31 st International Conference of the Red Cross Red Crescent on 'Strengthening normative frameworks and addressing regulatory barriers concerning disaster mitigation, response and recovery' (2011); Resolution 6 of the 32nd International Conference of the Red Cross Red Crescent on 'Strengthening legal frameworks for disaster response, risk reduction and first aid' (2015), available online at www.ifrc.org/dl.

${ }^{116}$ See the Constitution of the World Health Organisation (1946).
} 
Brookings Edu (2014) Understanding the economic effects of the 2014 Ebola outbreak in West Africa, Oct 2014

Campbell L (2017) Learning from the Ebola response in cities: population movement. ALNAP working paper

Checchi $\mathrm{F}$ et al (2016) World Health Organisation and emergency health: if not now, when? BMJ 352:i469

Clift C (2013a) The role of the World Health Organisation in the international system. Chatham House, Centre on Global Health Security Working Group Papers, p 6, Feb 2013

Clift C (2013b) The role of the World Health Organisation in the international system. Chatham House, Centre on Global Health Security Working Group Papers, p 7, Feb 2013

Clift C (2013c) The role of the World Health Organisation in the international system. Chatham House, Centre on Global Health Security Working Group Papers, Feb 2013. Executive summary Dupuy P-M (1991) Soft law and the international law of the environment. Mich J Int Law 12:420-435

Fidler DP (1997) The role of international law in the control of emerging infectious diseases. Bull Inst Pasteur 95:57, 59

Fidler D (1999) International law and infectious diseases. Clarendon, Oxford, p 5

Fidler D (2000) The role of international law in the control of emerging infectious diseases. In: Whitman J (ed) The politics of emergent and resurgent infectious diseases. Palgrave Macmillan, London, United Kingdom, p 65

Garrett L (2015) Ebola's lessons. Foreign Aff 94:80-107

Gostin LO (ed) (2014) Global health law. Harvard University Press, Cambridge, MA, p 177

Gostin LO (2015) Reforming the World Health Organisation after Ebola. JAMA 14:1407-1408

Harman S (2012) Global health governance. Routledge, New York, p 28

Howard-Jones N (1950) Origins of international health work. Br Med J 1:1032-1037

IFRC (2014a) Emergency Plan of Action (EPoA) update Guinea: Ebola virus disease, 18 Nov 2014

IFRC (2014b) Emergency Plan of Action (EPoA) revision Liberia: Ebola virus disease, 9 Apr 2014

IFRC (2014c) Emergency Plan of Action (EPoA) Sierra Leone: Ebola virus disease, 9 Sept 2014

IFRC (2014d) Red Cross responds to Ebola outbreak in Guinea, 25 March 2014. www.ifrc.org/en/ .../guinea/red-cross-responds-to-ebola-outbreak-in-guinea--65316/

IFRC (2015a) Beyond Ebola: from dignified response to dignified recovery. IFRC

IFRC (2015b) Terms of reference for real time evaluation of the IFRC response to the Ebola virus disease outbreak. In: Ebola real time evaluation report, 25 Jan 2015

IFRC (2015c) Terms of reference for real time evaluation of the IFRC response to the Ebola virus disease outbreak. In: Ebola real time evaluation report, p 3, 25 Jan 2015

IFRC (2017) Closer to communities means better response to health crises, 23 May 2017. https:// media.ifrc.org/ifrc/2017/05/23/closer-to-communities-means-better-response-to-health-crises/

Kamradt-Scott A, Harman S, Wenham C, Smith F III (2015) Saving lives: the civil-military response to the 2014 Ebola outbreak in West Africa, October 2015. http://sydney.edu.au/arts/ ciss/downloads/SavingLivesPDF.pdf

Kaplan J, Easton-Calabria E (2015) Military medical innovation and the Ebola response: a unique space for humanitarian civil-military engagement. Humanitarian Practice Network, June 2015. http://odihpn.org/magazine/military-medical-innovation-and-the-ebola-response-aunique-space-for-humanitarian-civil-military-engagement/

Koenig C (1991) Observer status for the International Committee of the Red Cross at the United Nations: a legal viewpoint. IRRC 280:47

Kupferschmidt K (2015) Global health: report prescribes strong medicine for WHO. Science 349:223-224

Lee K (2009) The World Health Organisation (WHO). Routledge

Mackey T (2016) The Ebola outbreak: catalyzing a "shift" in global health governance? BMC Infect Dis 16:699

Mackey T, Liang BA (2012) Lessons from SARS and H1N1/A: employing a WHO/WTO forum to promote optimal economic-public health pandemic response. J Public Health Policy 33:119-130 
Moon S et al (2015) Will Ebola change the game? Ten essential reforms before the next pandemic. The report of the Harvard-LSHTM Independent Panel on the Global Response to Ebola. Lancet 386:2204-2221

Murray A, Majwa P, Roberton T, Burnham G (2014) Inception report: real time evaluation of the IFRC response to the Ebola virus disease outbreak, 30 Nov 2014. In: Ebola real time evaluation report. IFRC, p 11, 25 Jan 2015

Ross E, Welch GH, Angelides P (2017) Sierra Leone's response to the Ebola outbreak management strategies and key responder experiences. Centre on Global Health Security, March 2017

Shoman H, Karafillakis E, Rawaf S (2017) The link between the West African Ebola outbreak and health systems in Guinea, Liberia and Sierra Leone: a systematic review. Global Health 13:1-22

Shucksmith C (2017) The International Committee of the Red Cross and its mandate to protect and assist: law and practice. Hart

Siedner MJ (2015) Strengthening the detection of and early response to public health emergencies: lessons from the West African Ebola epidemic. PLoS Med 12:e1001804

Skowronski DM et al (2005) Severe acute respiratory syndrome (SARS): a year in review. Annu Rev Med 56:357-381

Stein RA (2015) What is Ebola? Int J Clin Pract 69(1):49-58

Tiffany A et al (2017) Estimating the number of secondary Ebola cases resulting from an unsafe burial and risk factors for transmission during the West Africa Ebola epidemic. PLoS Negl Trop Dis 11(6):e0005491

WHO (1996) Division of emerging and other communicable diseases surveillance and control. Emerging and other communicable diseases strategic plan 1996-2000. WHO/EMC/96.1, Geneva, Switzerland

WHO (2015) The role of WHO within the United Nations mission for Ebola emergency response: report of the secretariat, April 2015

WHO, IFRC (2017a) The Regulation and Management of International Emergency Medical Teams, June 2017

WHO, IFRC (2017b) The Regulation and Management of International Emergency Medical Teams, pp 9-10, June 2017

WHO, IFRC (2017c) The Regulation and Management of International Emergency Medical Teams, p 19. IFRC and WHO, June 2017

WHO, IFRC (2017d) The Regulation and Management of International Emergency Medical Teams, p 25. IFRC and WHO, June 2017

WHO, IFRC (2017e) The Regulation and Management of International Emergency Medical Teams, pp 37-38. IFRC and WHO, June 2017

Wibulpolprasert S, Chowdhury M (2016) World Health Organisation: overhaul or dismantle? Am J Public Health 106:1910-1911

Wilson K, Brownstein J, Fidler DP (2010) Strengthening the international health regulations: lessons from the H1N1 pandemic. Health Policy Plan 25(6):505-509 